Teosofia: Indonesian Journal of Islamic Mysticism, Vol. 8, No. 1, 2019, pp. 69-80 e-ISSN: 2540-8186; p-ISSN: 2302-8017

DOI:

\title{
Negotiating Tradition and Innovation Upon the Cross-Generational Art of Singiran (Improvisation, Cultural Identity and Millennial Community)
}

\author{
Mohamad Sobirin \\ Faculty of Islamic Theology and Humanities \\ UIN Walisongo Semarang \\ mohamadsobirin@walisongo.ac.id
}

\begin{abstract}
:
This study, based on recent virtual observation, explores the process of cultural negotiations of singing Singiran among millennial. In addition, it also breaks down the strategies practiced by the Singiran musicians in introducing their artistic products into digital society. In this study, in addition to observing the lyrics and chords of Singiran, I interviewed Rijal Vertizon and his associates; the musicians who have popularity based on the number of their subscribers. The Singiran musicians regenerated the tradition of singing Singiran with innovation, especially upon the arrangement of the music, as well as developing a strategy to improve sounds and fulfill the aesthetic changes of populist Muslim markets and newly emerging millennial Muslim identities. In addition to reconstructing this traditional culture, Singiran musicians are interested in creating a positive image both for insiders and outsiders of Javanese cultures and reaching the larger Muslim community. My observations to the Singiran's enthusiasts show that innovative Singiran can play a role in shaping the cultural identity of the Javanese Millennial Muslim. In other perspective, it could be called as a new kind of local wisdom in contemporary Javanese life.
\end{abstract}

Keywords: Singiran, Innovation, Javanese Millennial, Cultural Identity, Negotiation

\section{A. Introduction}

T avanese people ${ }^{1}$ really like art. Various types of arts flourish in the Javanese community both in the form of music/karawitan, dance, literary arts, puppetry, theater arts, and fine arts. These various types of art lived both among the prijajis

1 Anthropologically Javanese people are people who in their daily lives use Javanese with various dialects for generations. Ismawati, "Budaya dan Kepercayaan Jawa Pra Islam" dalam Amin, Darori (editor), Islam dan Kebudayaan Jawa (Yogyakarta: Gama Media, 2000), 3. Javanese people residing in Central and East Java, or from both regions this, while Yogyakarta and Surakarta which are the former Mataram kingdoms are the center of Javanese culture. 
and the commoners and were entrenched in Javanese culture long before their entry Islam in Indonesia.

Since Islam had entered Java, the influence of Islamic culture did not bring about a complete collapse of the Javanese-Hindu-Javanese tradition, and even interesting interrelations between the two. The evidence of this interrelation can be seen in various activities of daily life or in the arts. One form of interrelation that is interesting between Islamic culture and Javanese tradition that has been passed down and down is singiran art that is found in various Javanese traditions.

The phenomenon of Singiran in various traditions and ceremonies is something typical of Java. Singiran, in this contemporary era is a form of Javanese sound art (tembang) which is not only sung and no longer voiced in tahlilan rituals, praises before five daily prayers in mosques and mushalla, but also in virtual media in the middle of millennial society. Phenomena's presence in the new media is interesting to study both in terms of art and reception and its function.

The focus of this research is the Singiran art that is performed in the digital space of millennial Javanese society with the case hearing on the Singiran performed by Rijal Vertizon, viewed from the perspective of cultural identity and from the perspective of his art form. The election of this character is based on the consideration that millennial Muslims in Indonesia accepted the presence of the song delivered by Rijal Vertizone enthusiastically and because of the song form that was improvised innovatively.

Thus this research is intended to answer the following two questions: (1) how were innovations implemented in Singiran delivered by Rijal Vertizon? (2) How is the Singiran intended by the millennial Muslim community in the context of Javanese Islamic culture?

\section{B. Method and Theory}

Data collection methods used here are participant observation, interviews, and digital documentation. The observation method is used to observe Singiran uploaded on the Rijal Vertizon youtube, with a reception in the form of comments, views and subscribers. Interviews were used to explore the form of songs and singing verses in the informants by learning from the informants, while the documentation is directed to find out the chanted script of Singiran. There are two informants of this research, namely:

1. Saiful Rijal (Rijal Vertizon), the singer of studied Singiran.

2. Deni Aden, friend of the first informant, also a singer of Islamic songs for millennials. 
The data collected through various techniques was analyzed using the theory of Ilmu 'arud wal qawafi and the theory of tradition in music proposed by Alan Stanbridge. In his article entitled "Tradition and Hybridity in Contemporary Music" he examine the eclectically hybrid nature of contemporary music, and its dynamic relationship with tradition. Focusing on the creative balance between tradition and innovation, he consider the recent output of several key record labels, including ECM, Winter \& Winter, and Tzadik. In the latter part of the paper, he explored the remarkable resurgence of the accordion in contemporary music, drawing on the work of Gianni Coscia, Jean-Louis Matinier, Stian Carstensen, and Guy Klucevsek, among others.

\section{Literature Review}

Singiran, as an object of study, has been studied with various approaches. Unfortunately, no recent studies have been found on Singiran produced in the last five years. I found for example in an article written by Kholid Mawardi entitled "Singiran: Pendekatan Sosio-kultural Pembelajaran Islam dalam Pesantren dan Masyarakat NU". ${ }^{2}$ Mawardi uses a socio-cultural approach to Singiran in the context of Islamic education. This study concludes that pesantren and NU people have a very tolerant view of local cultures; even they have the belief that Islamic laws need to be interpreted through local understanding. From such a view, pesantren and NU communities tend to be more creative and varied in conducting Islamic learning by using and entering local traditions, one of the socio-cultural approaches they use is singiran.

In the same context, is education, Moh. Muzakka, in his research "Puisi Jawa Sebagai Media Pembelajaran Alternatif di Pesantren (Kajian Fungsi terhadap Puisi Singir)", ${ }^{3}$ shows three functions of singir for the santri community, namely spiritual function (salvation, faith), social function (education, learning, management), and entertainment function (musicalisation, singing). These three functions are integrated into the learning framework of religious and scientific material in Javanese boarding schools. Because singir is quite effective in learning, singir has become an alternative learning medium for students.

2 Kholid Mawardi, "Singiran: Pendekatan Sosio-kultural Pembelajaran Islam dalam Pesantren dan Masyarakat NU”, dalam INSANIA: Jurnal Pemikiran Alternatif Kependidikan, Vol. 11 No.3 SepDes 2006 315-327.

3 Moh. Muzakka, Puisi Jawa Sebagai Media Pembelajaran Alternatif di Pesantren (Kajian Fungsi terhadap Puisi Singir)", dalam Makalah Kongres Bahasa Jawa IV, 2006, Semarang.

Teosofia: Indonesian Journal of Islamic Mysticism, Vol. 8, No. 1, 2019 
Another article using a functional approach was written by Kusnadi, entitled "Seni Singiran dalam Ritual Tahlilan Pada Masyarakat Islam Tradisional Jawa". ${ }^{4}$ This study concludes that the functions of Singiran in the context of the Tahlilan rituals are (a) as Islamic propagating medium, and (b) as a means of tightening brotherhood among the members of tahlil groups.

Meanwhile, there are studies that use linguistic approaches written by Hindun, entitled "Syingir: Transformasi Puisi Arab Ke Dalam Puisi Jawa". ${ }^{5}$ This study reveals that the Javanese Singer form has a similar pattern to traditional Arabic syiir called the al-khalil pattern. This is due to the background of the singers, namely the kiai who are familiar with the science of 'arud wal qafiyah, a science of making and composing pottery in Arabic. This knowledge influenced the Kiai in arranging the singles of his work.

\section{Discussion}

The term singir is thought to come from syi'ir Arabic which means poetry or poetry. Because the habits of the Javanese who read the letters' ain by playing, the term syi'ir changes to singir. The suffix shows the meaning of the game or imitation of the original, as in the term bedayan which means imitation of bedaya, srimpel from the word srimpi-srimpian.

Historically, it was difficult to trace when the singles or singles began. In the Centhini fiber which was created during the reign of Sunan Pakubuwono V, the term singir has appeared. In pupuh 321 (sinom), for example, it is told about the Duke of Wirasaba who claimed that he took the magic of Mas Cebolang after his son was born safely, as did his mother. It was revealed that at that time there were many spectators, including the Duke's assistants and concubines. It was also told that Mas Cebolang had a handsome face, and was decorated with beautiful clothes. When playing tambourine, singing, squealing his voice is melodious, clear and seductive, therefore many women fall in love. ${ }^{6}$

What is the shape of the song that was sung during Pakubhuwana V? In 321 centhini fibers, especially at 51-56, it was explained that the singir at that time was sung with three pieces of tambourine, angklung, kendang, calung, and calapita ivory. Chanted songs include the plates, gambirsawit, spells. The names are in front until now is still well known to the world of music. Based on the type of instrument used

4 Kusnadi, berjudul "Seni Singiran Dalam Ritual Tahlilan Pada Masyarakat Islam Tradisional Jawa”, dalam Imaji, Vol.4, No.2, Agustus 2006 : 230 - 243

5 Hindun, "Syingir: Transformasi Puisi Arab Ke Dalam Puisi Jawa," dalam Jurnal Humaniora, Vol. 24, No.1, Februari 2012: 73-83.

6 Marsono at.all., Centhini, Tambangraras-Amongraga, Jilid V (Yogyakarta: Gadjah Mada University Press), ix. 
and the song being played, what is called singir at that time is more like the santiswara or larasmadya that we encounter today. So that the gendhing-gendhing sounding from the sound was at that time besides using Arabic, also using Javanese.

Although the population is quite large, the presence of singir in Javanese literature is still far from the attention of literary experts. This was evidenced by the scarcity of research on singers produced by experts, even more ironic in various books on Javanese literature and / or Javanese language and literature textbooks such as the writings of Perbatjaraka and Tardjan Hadidjaja (1952), Padmosoekotjo (1960), Ras (1985), Subalidinata (1996) is not mentioned at all. In addition, in a study catalog of Javanese manuscripts such as catalogs of Pigeaud's composition (1973), Girardet (1983), and Behrend (1992) no single title of singir was recorded (Muzakka, 1999; Muzakka et al, 2002). In addition, Basuki also studied that the existence of Javanese poetry was never mentioned in the periodization of Javanese literature (Basuki, 1988: $30)$.

Although lacking the attention of experts, singers continued to grow rapidly among Muslim communities in Java. The presence of singir has shaped the behavior of singers of singir in a cultural nuance that is different from the Javanese, urban Javanese, and Javanese communities around the palace, namely the enactment of singir as a means of education and teaching of Islamic cultural values with a cultural approach that characterizes certain cultural identities.

The presence of singir in the Islamic community in Java is inseparable from its function as a means or means of learning in the community, namely making singir as praise which is presented in mushalla, langgar or mosque and at certain times in social religious activities such as tahlilan, manaqiban, and maulidan. The singles are usually sung together by the pilgrims before the Fajr, Dhuhr, Asr, Maghrib or Isha prayers while waiting for other members of the community to come together to establish congregational prayers. There are those who use Arabic and regional languages. Perhaps because of its rhythmic arrangement, the singir is easily memorized and spreads from one mushalla or mosque to other mushalla and mosques.

\section{Millennial Singiran: Innovating Performance}

The singir which is used as the object of study in this research is the one performed by Rijal Vertizon along with his colleagues. Rijal Vertizon has the real name Syamsul Rijal, a millennial generation who has an Islamic boarding school education background as well as formal education, and lives in the educational city of Yogyakarta, a city inhabited by a variety of people from the homeland of Indonesia, both in terms of ethnicity and religion. His presence in the digital space by bringing Islamic songs that are identical to the name Singir, has placed him as one of the millennial artists and musicians who have a peculiarity, thus getting a positive 
response from netizens. As of this writing, the total number of channel subscribers of the channel reached 96,549, while one of the albums, entitled "Mampir Ngombe" was watched 1.4 million times, while the total number of views made by Youtuber for all his works reached 27,672,082 times.

Singirs that were originally synonymous with traditionality and among the elderly, and often only found through traditional and classical and traditional stages, are transformed by Rijal Vertizon and their teams into a new stage that is identical to the millennial world. Rijal's appearance indicates the occurrence of Islamic identity hybridization with Java; he sang songs with Islamic messages, but used Javanese and wore blangkon and Javanese clothing. The message he wanted to convey to the millennial was that Islam should not be contrasted with various localities in the archipelago, in this case Java. The performance he presented represented Javanese cultural accommodation towards Islam, and vice versa.

Digital stage which was used by Rijal in singing singir, was acknowledged by him as the choice he took in transforming traditional values in Islamic da'wah that had been carried out by Walisongo and his successors from the Kiai. He believes that millennial generations whose activities are widely spent surfing the virtual media world, also have the same need for spirituality, but which are compatible with their style and inclination. Singiran, as a nation's cultural treasure that must be preserved will not be easily accepted by millennials if without being presented innovatively in accordance with the popular character inherent in the millennial way of life.

\section{Millennial Singiran: Innovating Arrangement}

Rijal Vertizon released many Islamic songs, some were solo and some performed with other singers. The songs include those with Indonesian and Arabic Islamic songs, Sholawatan, and Singiran. In this study I only chose Singiran genre, namely (1) Kagungane Allah, (2) Mampir Ngombe, (3) Pejah Khusnul Khotimah, (4) Turi Putih, (5) Lir Ilir, (6) Lajering Iman, and (7) Sluku-Sluku Bathok. Numbers 1 through 3 were sung solo, while numbers 4 to 7 he sang with Saddam Kiwo's feat. In this section, I will only analyze the first 2 Singles, to show the innovations made. Here are the lyrics from the three singers that I analyzed:

(1) Kagungane Allah

Inna sholati wa nusuki wamahyaya

Wa mamati lillahi rabbil 'alamin

Setuhune sholat kulo ibadah kulo

Gesang kulo pejah kulo kagungane Allah

Inna sholati wa nusuki wamahyaya

Wa mamati lillahi rabbil 'alamin 
Setuhune kulo sanes ahli suwargo

Tapi kulo mboten kiat ing neroko

Reff:

Ya Allah kulo nyuwun, kulo nyuwun ngapuro

Sekabihe duso kulo lan tiyang sepah kulo

Mugio panjenengan paring rohmat ing kulo lan tiyang sepah kulo

Lan umat Islam sedoyo

Mugi-mugi panjenengan paring rahmat ing kulo lan umat islam sedoyo Allahumagfirli wa liwa lidaya war hamhuma kama robbayani shagira $2 x$

This bait has bahr rajaz pattern and consists of 6 metrum. The following is the description:

\begin{tabular}{lll}
\hline Metrum 1 & Metrum 2 & Metrum 3 \\
\hline Inna sholati & wa nusuki & Wamahyaya \\
\hline Metrum 4 & Metrum 5 & Metrum 6 \\
\hline Wa mamati & Lillahi rab & bil 'alamin \\
\hline
\end{tabular}

Each metrum in rajaz bahr consists of 4 beats based on consonants and vowels, for example the following metrum:

\begin{tabular}{lcccc}
\hline Number of beats & 1 & 2 & 3 & 4 \\
\hline Metrum & In-na & sho & La & $T i$ \\
\hline
\end{tabular}

It's just that the above singir after being arranged and diluted with Javanese and pop melodies, the metrum turned into 8 and the beats into two and four beats four times in one byte as follows:

\begin{tabular}{llll}
\hline Metrum 1 & Metrum 2 & Metrum 3 & Metrum 4 \\
\hline Inna sholati & wa nusuki & Wamah & Yaya \\
\hline Metrum 5 & Metrum 6 & Metrum 7 & Metrum 8 \\
\hline Wa mamati & Lillahi rab & Bil & 'Alamin \\
\hline
\end{tabular}

(2) Mampir Ngombe

(La ilaha illallah $3 \times$ muhammadur rasullah $1 \times$ ) x3

Reff:

Ojo siro banget-banget seneng-seneng nong alam dunyo

Malaikat juru pati plirak plirik marang siro

Olehe nglirik malaikat arep njabut nyowo siro 
Olehe njabut anganteni dawuhe kang moho mulyo (La ilaha illallah $3 \times$ muhammadur rasullah $1 \times$ ) $\times 2$

Reff:

Ojo enak-enak turu, ilingo marang patine

Yen dipundut gusti Allah, manungso karik getune

Umur manungso mbendino sudo, ayo poro konco ndang tobato

Urip ning dunyo pirang suene, diumpamakno mung mampir ngombe

(La ilaha illallah 3x muhammadur rasullah $1 \times$ ) x3

Unlike the bait (1), this bait is patterned as bahr wafir majzu' because it consists of only 4 of the six metrum. The four metrums are contained in each bait. The following is the description:

\begin{tabular}{llll}
\hline Metrum 1 & Metrum 2 & Metrum 3 & Metrum 4 \\
\hline la ilaha & Illallah & muhammadur & rasulullah \\
\hline
\end{tabular}

Each metric in bahf wafir consists of 4 beats based on mutaharrik and sakin, for example the following metrum:

\begin{tabular}{lcccc}
\hline Jumlah Ketukan & 1 & 2 & 3 & 4 \\
\hline Metrum Singir di atas & la & $i$ & la & ha \\
\hline
\end{tabular}

It's just that the above singir after being arranged and cuddled with Javanese and pop melodies, the metrum is turned into 8 and the tap into two and four taps four times in one byte as follows:

\begin{tabular}{llll}
\hline Metrum 1 & Metrum 2 & Metrum 3 & Metrum 4 \\
\hline La ilaha & illallah & La ilaha & illallah \\
\hline Metrum 5 & Metrum 6 & Metrum 7 & Metrum 8 \\
\hline La ilaha & illallah & muhammadur & rasulullah \\
\hline
\end{tabular}

The arrangement carried out by Rijal Vertizone and his team towards Singir so as not to fully follow the Shi'ir method in Arabic, because it is adapted to the pop melody which is a melody that is favored by millennial teens. Even so, the nuances and tones displayed do not leave the strains of Javanese songs. So that the innovation given to Singiran that was sung was able to touch the melody of millennial music, namely pop, without leaving the feel of Javanese tones. 


\section{New Functions: Singiran in the Context of Millennial Muslim}

Demographically, "millennial Muslims" (the language used by Jeff Diamant and Claire Gecewicz, researchers of religious studies at the Pew Research Center, 2017) are one generation born from 1981 to 1999. Most of these generations have transitioned to the adult, and medium or graduate from college. Some have started careers or started fostering families. Meanwhile, Shelina Janmohamed (2016) reveals the character of "Generation M" is faith and modern life, both as two things that are carried out simultaneously without contradiction. The wave of this generation around the world is starting to move, showing its existence through behavior and attitudes that create new trends in various accents of global life. Islamic reference demands that are popular genre, how to obtain religious teachings through new internet-based media, and virtual-digital-based religious spaces have finally become identical characters inherent in this generation.

Singiran as a literary work, by Rijal Vertizone, has been developed into musical art. This transformation has implications for the development of authentic singular functions as a medium of da'wah and learning in the middle of the Javanese Muslim community, towards other functions that are identical to the various millennial Muslim receptions. My observation shows the dynamic function of the quotient for millennial Muslims into three types; popular entertainment function, affirmation function of cultural identity hybridity, and millennial moral control function.

\section{Entertaining Function}

Just as the song function in the music world is to bring entertainment to its listeners, Singiran performed by Rijal Vertizone is also intended to provide entertainment for anyone watching and listening to it. This is different from Singiran which is traditionally performed, which seems to ignore this aspect of entertaining and prioritizes its main purpose as a media for delivering Islamic messages. Rijal considers the entertaining aspects of Singiran that he sings more specifically and seriously. This aspect includes audio visuals that are worked out not amateurishly, but through professional production houses, so as to be able to provide entertaining effects to the audience and listeners.

HD video image quality and crystal clear voice encourage yuotubers to subscribe to the RI Vertizone channel and like the Singiran they produce. The entertaining effect produced by Singirs delivered by Rijal cannot be separated from the arrangement that is more contemporary. Innovation through this arrangement was carried out because it considered the segment intended by Rijal Vertizone, namely Netizens who are in fact classified as millennials. So even though the lyrics sung are traditional, the packaging presented is nuanced in the present 


\section{The Shaping of Cultural Identity Function}

The cultural identity of a group is shaped by a culture that is inherently identical to it. Music is a part of the culture that forms the intended identity, especially regional music that stores local wisdom. Singiran as a marriage product between Javanese culture and Islam has been able to become part of the culture that forms the cultural identity of the Javanese Muslim community. It's just that, along with the development of the disruptive era, the Javanese Muslim cultural identity formed by the nembang tradition with Singiran has become faded and excluded by national religious music (in Indonesian) and imported from outside (in English and Arabic), as a result of globalization and advancement of information technology. For example, Javanese Muslims are more fond of listening to Nisa Syabyan and Maher Zain than Singers who have existed since the Walisongo era. This development presents the phenomenon that Singiran is no longer able to become a part of Javanese culture that helped shape the cultural identity of Javanese Muslims, especially Millennial Javanese Muslims.

Under these conditions, the presence of Rijal Vertizone and its team in the last five years with meaningful innovation in singular has given another value to the singular itself, and to the possibility of what is called a hybrid cultural identity for millennial Javanese Muslims. Singiran traditional values have been combined with pop values which are the main trends of millennials, including Millennial Muslim Javanese. Through Singiran in the style of Rijal Vertizone, Millennial Muslim Muslims are not reluctant to know Singiran as part of their cultural identity. This is evidenced by their great interest in innovative Singiran as much as their interest in popular Islamic music. Innovations that carry modern music arrangements make Singiran sung by Rijal Vertizone perched on the top Islamic music preference playlist for Millennial Javanese Muslims. Thus, it can be said that innovative Singiran has been able to help shape the cultural identity of Millennial Javanese Muslims, and restore the authentic role of Singiran as one of the music forming the Javanese Muslim cultural identity.

\section{Spiritual-Ethics Engagement Function}

Rijal Vertizon argued that the swift production of various types of entertainment in cyberspace needs to be balanced with entertainment that presents the coolness and values of local wisdom. Singiran as literary works as well as musical works of art are part of local wisdom that carries the values of spirituality and ethics. The lyrics convey a message about the nature of life and death, divinity and humanity, worship and faith, and for example those that are met with various things that are local Javanese are able to answer the spiritual needs of millennials.

In that context, innovative Singiran by Rijal Vertizon has a position among millennial Muslim netizens as a virtual service for spiritual ethics engagement for them. Its existence provides messages of spirituality and ethics through the art of 
music, so it is more effectively accepted. Millennial Javanese Muslims like finding an oasis in the midst of the lack of spirituality in the digital world when they find Singiran of Rijal Vertizone. This is also the goal of Rijal Vertizone in presenting its innovative Singiran in the middle of the millennial in the digital world.

\section{E. Concluding Remarks}

Singiran has experienced the process of continuity and change. What continues to be perpetuated in Singiran up to the contemporary is the essential aspect of Singiran, that it is the local wisdom of early Islamic disseminators in the land of Java and the archipelago in spreading Islam with the process of integrating Islamic moral messages with Javanese culture and traditions, namely tembangan, whereas what the change from the Singiran tradition by Singiran musicians today is the performative and aesthetic-artistic aspects of Singiran. He is no longer sung in places of worship and ceremonial rituals, but in the middle of a digital pulpit witnessed by millennials, besides Singiran is no longer sung with traditional musical instruments, but uses various modern musical instruments and in arrangements with special musicalisation.

The function of singir, which was once a medium of Islamic learning and $d a^{\prime} w a h$, is also a manifestation of its tradition of cultural tolerance. At present, its function has also developed to form Java's millennial Muslim identity through the musical preferences they have towards innovative engravings. Millennial Muslims are often synonymous with those who have given up traditional values and put forward modernity, with the presence of innovative Singiran, making them sympathetic to traditionality and the values it contains. This function reinforces the existence of Singiran's role that has succeeded in answering the needs of millennial generation through the popular packaging that it carries. Singiran sung by millennial generation representations through virtual media with innovations in several aspects have succeeded in becoming part of popular culture which is the main character of millennial communities. 


\section{Bibliography}

Hindun. 2012. "Syingir: Transformasi Puisi Arab Ke Dalam Puisi Jawa," in Jurnal Humaniora, Vol. 24, No.1, Februari 2012: 73-83.

Ismawati. 2000. "Budaya dan Kepercayaan Jawa Pra Islam" dalam Amin, Darori (editor), Islam dan Kebudayaan Jawa. Yogyakarta: Gama Media.

Kusnadi. 2006. "Seni Singiran Dalam Ritual Tahlilan Pada Masyarakat Islam Tradisional Jawa", in Imaji, Vol.4, No.2, Agustus 2006: 230 - 243

Marsono at.all. Centhini, Tambangraras-Amongraga, Jilid V (Yogyakarta: Gadjah Mada University Press).

Mawardi, Kholid. 2006. "Singiran: Pendekatan Sosio-kultural Pembelajaran Islam dalam Pesantren dan Masyarakat NU", in INSANIA: Jurnal Pemikiran Alternatif Kependidikan, Vol. 11 No.3 Sep-Des 2006 315-327.

Muzakka, Moh. 2006. Puisi Jawa Sebagai Media Pembelajaran alternatif di Pesantren (Kajian Fungsi terhadap Puisi Singir)", in Makalah Kongres Bahasa Jawa IV, 2006, Semarang. 